\title{
Lojistik Sektöründe Çalışan Kadınların Motivasyonlarının Cam Tavan Algıları Açısından Değerlendirilmesi ${ }^{1}$
}

\section{Kader YANMAZ ${ }^{2}$ \\ Oya KORKMAZ ${ }^{3}$}

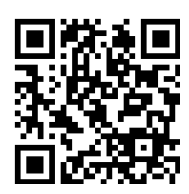

\begin{tabular}{|c|c|}
\hline $\begin{array}{c}\text { Geliş Tarihi/ Received } \\
14.09 .2020\end{array}$ & $\begin{array}{c}\text { Yayın Tarihi/ Published } \\
15.07 .2021\end{array}$ \\
\hline $\begin{array}{l}\text { Citation/Atıf: Yanmaz, K. } \\
\text { Motivasyonlarının Cam Tavan } \\
\text { Idari Bilimler Dergisi, 35(3): }\end{array}$ & $\begin{array}{l}\text { kmaz, O., (2021), Lojistik Sektöründe Çalışan Kadınların } \\
\text { l Açısından Değerlendirilmesi, Atatürk Üniversitesi İktisadi ve } \\
\text { 05-832, https://doi.org/10.16951/atauniiibd.793527 }\end{array}$ \\
\hline
\end{tabular}

Öz: Bu çalışma, cam tavanın motivasyon ile olan ilişkisini ortaya koymak ve cam tavanı kırmanın kadın çalışanların motivasyonu üzerinde yaratacağı olumlu etkileri yöneticilere ve işletme sahiplerine göstermek ve onlarda bu konu hakkında bir farkındalık yaratmak amacıyla yapılmıştır. Ayrıca bu çalışma insan kaynağı yönetiminin temel işlevlerinden biri olan kariyer yönetiminin önemini ortaya çıkarmak, kariyer yönetiminin etkin bir şekilde kullanımı sayesinde kadın çalışanların motivasyonunun artırılabileceğini karar alıcılara göstermek amacıyla yapılmıştır. Olasılıklı olmayan örnekleme yöntemlerinden amaçlı örnekleme yönteminin kullanıldı̆̆ lojistik firmalarında çalışan 100 beyaz yakalı kadın çalışandan elektronik ortamda anket yöntemiyle veri elde edilmiştir. Elde edilen bu veriler SPSS ve AMOS paket programları kullanılarak değerlendirilmiştir. Değerlendirmeler sonucunda cam tavan algısı ile genel motivasyon ve genel motivasyonun dışsal boyutu arasında negatif yönde ve düşük düzeyde anlamlı bir ilişki olduğu saptanmıştır. Ayrıca bu çalışmada cam tavan algısının oluşmasında cam tavanın; cinsiyet ayrımcılığı, aile hayatı, örgüt kültürü ve politikaları alt boyutlarının da etkili olduğu tespit edilmiştir.

Anahtar Kelimeler: Cam Tavan Sendromu, Motivasyon, Lojistik Sektörü

\section{Evaluation of the Motivation of Women Working in the Logistics Sector in Terms of the Perception of Glass Ceiling}

Abstract: This study was conducted to reveal the relationship between the ceiling glass and motivation and to show the managers and business owners the positive effects of breaking the ceiling glass on the motivation of female employees to create awareness among those managers and business owners. Additionally, this study was conducted to reveal the importance of career management, which is one of the basic functions of human resources, and to show the decision makers that it is possible to increase the motivation of female employees through effective use of career management. The data obtained were evaluated using SPSS and AMOS package programs. As a result of the evaluations it was determined that there was a low level significance in the negative direction between the perception of glass ceiling and general motivation and the external dimension of motivation. Additionally, it was determined that there was a low level significance in the negative direction between "gender discrimination, family life, organizational culture and organization politics", which are sub-dimensions of glass ceiling perception, and general motivation.

Keywords: Glass Ceiling Syndrome, Motivation, Logistics Sector.

Jel Codes: D23, J24, J70, M12, M54

${ }^{1}$ Bu çalışma Doç. Dr. Oya KORKMAZ'ın danışmanlığında yürütülen "Lojistik İşletmelerinde Cam Tavan Sendromu ve İs Motivasyonu: Mersin İli Örneği” başlıkl yüksek lisans tezinden türetilmiştir. ${ }^{2}$ https://orcid.org/0000-0003-4577-5320,kaderyanmaz_9@hotmail.com

${ }^{3}$ Doç. Dr., Tarsus Üniversitesi, Uygulamalı Bilimler Fakültesi, Uluslararası Ticaret ve Lojistik Bölümü, https://orcid.org/0000-0003-4570-803X,oyakorkmaz67@tarsus.edu.tr 
Lojistik Sektöründe Çalışan Kadınların Motivasyonlarının Cam Tavan Algıları Açısından Değerlendirilmesi

\section{EXTENDED SUMMARY}

\section{Research Problem}

The aim of this study is to investigate the effects of the glass ceiling perceptions of women employed in the logistics industry on their work motivation.

\section{Research Questions}

The following research questions were included in the study to identify how and to what extent the glass ceiling perceptions of women employed in the logistics industry affect their work motivation:

Is there a significant relationship between the glass ceiling perception and general motivation?

Is there a significant relationship between the glass ceiling perception and internal motivation?

Is there a significant relationship between the glass ceiling perception and external motivation?

Do the dimensions of glass ceiling have a significant effect on general motivation?

Do the dimensions of glass ceiling have a significant effect on internal motivation?

Do the dimensions of glass ceiling have a significant effect on external motivation?

\section{Literature Review}

When the national and international literature are analysed, it can be seen that the number of studies investigating the relationship between the glass ceiling syndrome and work motivation, in particular, are very few. Moreover, it was found that studies investigating the relationship between these two variables in the logistics industry do not exist at all. Therefore, this study bridges the gap in the literature and contributes to the logistics industry.

The study carried out by Çakar Özenç and Salepçioğlu (2019) to identify the relationship between the glass ceiling perceptions of female pilots and female police officers and their work motivation is one of the limited number of studies investigating the relationship between the glass ceiling perception and work motivation. In this study, Çakar Özenç and Salepçioğlu (2019) determined a relationship between the glass ceiling perceptions and general and internal motivation of women that is positive in a statistical sense and has a high significance level whereas a relationship that is negative in the statistical sense and has a medium significance level was found between their glass ceiling perceptions and external motivation. These findings indicate that occupational discrimination against women increases the general and internal motivation of women whereas such discrimination reduces their external motivation (Çakar Özenç and Salepçioğlu, 2019: 329). 


\section{Methodology}

Purposeful sampling method, which is one of the non-probability sampling methods, was used in the study. Data was obtained from 100 white collar female workers employed by logistics firms operating in the city of Mersin in the electronic environment via survey method using the glass ceiling syndrome and work motivation scales. The data obtained were evaluated using the SPSS and AMOS package programs. Confirmatory Factor Analysis (CFA) was used in the determination of the structural validity of the scales used in the study, reliability analysis was used in the determination of internal consistency, correlation analysis was used to determine the direction and volume of the relationship between the variables, multiple regression analysis was used to investigate the relationship between the variables, and independent samples t-test and one-way ANOVA test were used to identify differences.

\section{Results and Conclusions}

The analyses revealed a low level significant relationship in the negative direction between the glass ceiling perception and general motivation. Furthermore, a low level significant relationship in the negative direction was found between the external sub-dimension of motivation and the glass ceiling perception. On the other hand, no significant relationship was determined between internal motivation, which is another sub-dimension of motivation, and the glass ceiling perception.

Investigation of the relationship between the sub-dimensions of the glass ceiling perception and general motivation, on the other hand, revealed that the gender discrimination, family life, organizational culture and policies subdimensions of the glass ceiling perception have a low level significant relationship in the negative direction with general motivation.

Investigation of the relationship between the sub-dimensions of the glass ceiling perception and the internal aspect of motivation, on the other hand, indicated a relationship between organizational culture and policies, which are sub-dimensions of the glass ceiling perception, and internal motivation that is in the positive direction and has a low level significance. A low level significant relationship in the negative direction was found between promotion of women in their vocational careers, which is a sub-dimension of the glass ceiling perception, and internal motivation.

As for the relationship between the family life, organizational culture and policies, gender discrimination sub-dimensions of the glass ceiling perception and external motivation; a low level significant relationship in the positive direction was determined between external motivation and the family life, organizational culture and policies sub-dimensions of the glass ceiling perception. A low level significant relationship in the negative direction was found between the glass ceiling perception and the sub-dimension of gender discrimination. 
Lojistik Sektöründe Çalışan Kadınların Motivasyonlarının Cam Tavan Algıları Açısından Değerlendirilmesi

\section{Giriş}

Toplumun yarısını oluşturan kadınların iş hayatına girmesiyle birlikte devrim niteliğinde bir gelişme yaşanmıştır. Kadınların eğitim seviyesinin her geçen gün artması kadınların iş hayatında her geçen gün daha fazla yer edinmesini sağlamıştır. Ancak bu olumlu gelişmelere rağmen kadın çalışanların hala üst yönetim pozisyonlarında yeterince temsil edilmedikleri görülmektedir. $\mathrm{Bu}$ durumun birçok sebebi olmasına rağmen, asıl sebebinin görülmez bir engel olan cam tavan olduğu bilinmektedir. Kadın çalışanların üst düzey yönetim pozisyonlarına yükselmesinde karşılaştıkları zorluklar olarak da bilinen cam tavan birçok araştırmacının dikkatini çekmektedir.

Çalışanların motivasyonu açısından kariyer yönetimi oldukça önemlidir. Kadın çalışanların kariyer yönetimini olumsuz yönde etkileyen cam tavan kadın çalışanların iş yerinde erkek çalışanlara göre daha az motive olmasını sağlamaktadır. Fakat cam tavanı kırarak kendini ispatlamayı başaran kadın çalışanların motivasyon düzeylerinin oldukça yüksek, bunun yanında cam tavana maruz kaldığını düşünen kadın çalışanların ise motivasyon düzeylerinin oldukça düşük olduğu görülmektedir (Akdemir ve Çalış Duman, 2017: 517). Kadın çalışanların yönetim rollerine terfi ettirilmesi sırasında ortaya çıkan engeller kadın çalışanların motivasyonunu bozabilmekte ve böyle bir durumda kadın çalışanlar bulunduğu konumu koruma yönünde motive olabilmektedirler. Ayrıca iş yerinde kendilerine rol model olabilecek yeteri kadar kadın çalışan ve üst yönetim pozisyonuna yükselmiş kadın yöneticilerin bulunmaması durumu da kadın çalışanların motivasyon kaybı yaşamasına neden olmaktadır. Yaşanan bu motivasyon kaybı kadınların var olan potansiyelinden yeteri kadar yararlanılamamasına ve kurum kaynaklarının boşa harcanmasına yol açmaktadır.

Kadın çalışanların en büyük motivasyon kaynağı örgütün kadın lehine oluşturduğu ve uyguladığı stratejiler ve araçlardır. İnsan kaynağının değerini anlayan örgütler bugün kadın çalışanların çalışma koşullarının iyileştirilmesine yönelik bir dizi politikalar üreterek rekabet üstünlüğü elde etmeyi ve toplum nezdinde saygın bir işletme olmayı hedeflemektedirler. Kısacası kadın çalışanların örgütle uyumu en büyük motivasyon kaynağı olmaktadır. Bu tür örgütlerde daha fazla kadın çalışan istihdam edilmektedir. Kadın çalışan sayısının modern toplumlarda artması kadın çalışanların motivasyonu konusunun zemin bulmasına ve üzerinde çalışılması gereken önemli bir konu haline gelmesini sağlamıştır.

Kadın çalışanların kendini ispatlamasına imkân veren örgütlerin kadın çalışanlarının moral ve motivasyonunu artırdıkları görülmektedir. Kadın çalışanların sahip oldukları bu yüksek moral ve motivasyon kadın çalışanların ekip oluşturmasına ve üretkenliğe katkıda bulunmasına yol açmaktadır. Motivasyon kavramının ortaya çıkardığı bu olumlu sonuçların farkına varan örgütler bireysel ve örgütsel amaçlar arasındaki uyuma dayanan kendi motivasyon sistemlerini inşa etmektedirler. Bu tür örgütler kadın çalışanlarının iş 
motivasyonlarını örgütsel stratejiler ve yönetim uygulamaları yoluyla artırmaktadırlar.

Bugünün insan kaynağı yönetiminin amaçları yani uğraşları arasında yer alan kadın çalışanların motive edilmesi konusu insan kaynağı çalışmalarında oldukça önemli bir yer tutmaktadır. Kadın çalışanların motivasyonu konusu örgütsel performansı artırmada aranan yeni yollar arasında yer almaktadır. Aranan bu yeni yollar arasında yer alan kadın çalışanların motivasyonu konusu motivasyona farklı açıdan yani cinsiyet açısından bakılmasını sağlamıştır.

Kadın ve erkek çalışanları motive eden faktörlerde farklılıklar görülmektedir. Erkek çalışanları motive eden ekonomik faktörlerin; kazanma eğilimi, iş özerkliği, terfi, tanınma, başarı ve eğitim gibi faktörler olduğu görülürken, kadın çalışanları motive eden alternatif faktörlerin ise işbirliği, çalışma koşulları, iyi bir yaşam alanı ve sosyal yardım şeklinde gerçekleştiği görülmektedir (Arnania-Kepuladze, 2010: 88). Liderlerin çalışanlarını yönetirken bu hususları ve kadın çalışanların erkeklere göre daha kariyer odaklı olduklarını göz önünde bulundurmaları gerekmektedir. Kadın ve erkek farklı mentaliteye sahip olduğundan onları motive eden faktörlerin de farklı olduğu unutulmamalı dolayısıyla kadın ve erkeği motive eden faktörler anlaşılmaya çalışılmalıdır. Bunun yanında kadın çalışanların motivasyonunu olumsuz yönde etkileyen faktörlerin de tespit edilip ortadan kaldırılması gerekmektedir. $\mathrm{Bu}$ nedenle bu çalışmada kadın çalışanların motivasyonunu olumsuz yönde etkilediği düşünülen cam tavanın motivasyon ile olan ilişkisi araştırılmış ve cam tavanı ortadan kaldırabilecek önerilerde bulunulmuştur.

\section{Cam Tavan Kavramı}

Kadınların işgücüne katılma oranının günden güne artmasına ve kadın ekonomisi kavramının "she-economy" her geçen gün dünyada daha çok kabul görmesine rağmen, (Can vd., 2018: 52) kadın çalışanlar operasyonel işlerle sınırlı kalmakta, çok azı idari işlerde görev almaktadırlar. Yönetim kademelerini bir buz dağına benzetecek olursak çok az sayıda kadın çalışanın üst yönetim kademesine ulaştığı yani buz dağının tepesine çıktığı görülmektedir (Sahoo ve Lenka, 2016: 313). Yönetim literatüründe cam tavan olarak adlandırılan bu durum kadınların üst yönetim düzeylerine ulaşamamalarının nedenlerinden biri olarak görülmekte ve kadın çalışanın hak etmesine ve başarısına bakılmaksızın ilerlemesini önleyen tüm engeller şeklinde ifade edilmektedir. Bu durum yönetimde ciddi problemler yaratmakta ve kadınların kariyer gelişimini olumsuz yönde etkilemektedir (Yörük Karakılıç, 2019: 215).

Cam tavan sendromu ilk defa 1970 yılında Amerika Birleşik Devletleri'nde psikoloji alanında yapılan bir deney sonucu ortaya çıkmıştır (Kurt ve Akgün Kostak, 2019: 860). Bu deneyden sonra cam tavan kavramı ilk defa 1986 y1lında Wall Street Dergisinde yayınlanan Hymowitz ve Schellhardt tarafından kaleme alınan iş kadınları hakkındaki bir yazı ile gündeme gelmiştir. Hymovitz ve Schellhard (1986) bu yazıda kadınların üst yönetim kademelerine 
iş gelenekleri ve klişelerden dolayı gelmelerinin önlendiğini ve bu durumun bir sendrom haline geldiğini ifade etmişlerdir. Hymovitz ve Schellhard (1986) cam tavan kavramını kadınların kurumlarında üst yönetim pozisyonlarına gelmelerini engelleyen kısıtlamalar olarak tanımlamışlardır (Yörük Karakılıç, 2019: 218)

İşletmelerde cam tavana neden olan faktörler; bireysel, örgütsel ve sosyal (toplum ve örgüt kültürü) faktörler olmak üzere üç grup altında toplanmaktadır. Cam tavan sendromunun oluşmasına neden olan ilk bireysel faktör kadının birden fazla rol üstlenmesi durumunu içermektedir. Kadından iyi bir eş, iyi bir anne ve iyi bir ev hanımı olmasının beklenilmesi kadının iş yaşamında başarılı olmasını zorlaştırmaktadır. Cam tavan sendromunun oluşmasına neden olan ikinci bireysel faktör ise kadın çalışanların bireysel tercihleridir. Kadının eve geldiğinde üstlendiği annelik, eş ve komşuluk rolü kadının iş hayatını ikinci plana atmasına neden olmaktadır (Yörük Karakılıç, 2019: 219).

Örgütsel faktörler ise bir örgütte erkek egemen bir örgüt yapısının olması, ve erkek çalışanların kadın yöneticilerden emir almayı uygun bulmaması durumunu içermektedir. Kadın yöneticilerin, yönetici kadın adaylara koyduğu engeller de bu faktör altında değerlendirilmektedir (Yörük Karakılıç, 2019: 219).

Cam tavana neden olan bir başka faktör ise sosyal faktörler yani toplum ve örgüt kültürüdür. Bazı toplumlarda hâkim anlayış kadın ve erkeğin eşit olmadığı yönündedir. $\mathrm{Bu}$ tür toplumlarda toplum düzeni cinsiyet eşitsizliği üzerine kurulmuştur. $\mathrm{Bu}$ tür toplumlarda önemli pozisyonlara gelmek erkekler için kaçınılmazdır. Erkeklerin sorumluluğunda önemli kararlar alınmaktadır. Buna karşın bu tür toplumlarda bir kadından emir almak toplumun bireylerini kızdırabilmektedir. Görüldüğü üzere kadın çalışanların yükselişinin önündeki en önemli engel toplumun kadın çalışanların yükselişini kabul etme düzeyidir (Yörük Karakılıç, 2019: 220).

Cam tavanın oluşmasına neden olan başka sosyal faktörler ise mesleki engeller, iletişim ağına katılamama ve basmakalıp/klişe önyargılardır. Sosyal faktörlerden ilki olan mesleki engeller; bazı meslek gruplarının belirli bir cinse atfedilmesi durumunu, toplumun kültürünü, kadın ve erkeklerin yetiştirilme biçimlerini ve toplum tarafindan insanlar üzerine dayatılan ilkeleri kapsamaktadır (Yörük Karakılıç, 2019: 220).

Sosyal faktörlerden ikincisi olan iletişim ağına katılamama durumu ise erkek egemen yapının ve formal iletişim ağının var olduğu işletmelerde kadın çalışanların formal iletişim ağına kabul edilmemesi yani bu ağa katılamaması durumunu ifade etmektedir. Kadın çalışanların formal iletişim ağına dâhil edilmemesi kadın çalışanların iletişim ağına katılamama durumu kapsamında değerlendirilmektedir (Yörük Karakılıç, 2019: 220).

Basmakalıp/klişe önyargılar ise örneğin; yöneticilerin erkek, kadınların hemşire olma yönündeki önyargılardan oluşmaktadır. Böylece birçok toplumda var olan bu basmakalıp/klişe önyargılar kadının çalışma hayatını etkilemekte, kadının yönetici pozisyonunda rol model olmasını ve kadının bu rollere uygun olabileceği fikrini engellemektedir (Yörük Karakılıç, 2019: 220). 
Cam tavana neden olan bir başka faktör ise "Mini-me" sendromudur. "Mini-me" sendromu bir yöneticinin kendi yerini alacak bir yönetici adayını seçerken (halef); liderlik stili, yaş ve cinsiyet bakımından kendisine benzer adayları tercih etmesi durumunu ifade etmektedir. Seçicilikteki bu algı durumu cam tavan sendromuna yol açmaktadır (Sahoo ve Lenka, 2016: 313).

Cam tavan örgütsel önyargıların yarattığı görünmez, yapay, şeffaf engellerdir ve kadınların üst yönetim seviyesine gelmesini engelleyen kalıplardır. Genelde literatürde en fazla erkek yöneticilerin kadın yönetici adaylarına karşı koyduğu engellerden bahsedilmektedir. Oysaki kadın yöneticilerin de azımsanmayacak ölçüde kadın yönetici adaylarına karşı koyduğu engeller bulunmaktadır. Kadın yöneticiler tarafından yaratılan bu engellere kraliçe arı sendromu denilmektedir (Yörük Karakılıç, 2019: 219). Kraliçe arı sendromu, "diğer kadınları geride tutan ya da hemcinsleri için başarı merdivenini tıkayan kadının neden olduğu sendrom" olarak bilinmektedir (Cummins, 2012: 80). Kraliçe arı sendromuna göre, gücünü korumaya çalışan bir kadın yani üst yönetim pozisyonunda bulunan bir kadın, üst yönetim pozisyonuna yükselmek için mücadele eden genç meslektaşları için bir tehdit oluşturmaktadır. Bu tip yönetici üst yönetimde tek kadın olmak için mücadele etmekte, yükselmek için mücadele eden genç kadın meslektaşlarının terfi ve kariyerlerindeki ilerlemelerini engellemektedir (Yörük Karakılıç, 2019: 220).

Üst yönetim pozisyonunda çok az sayıda kadın çalışanın bulunmasının sebeplerinden birisi de sosyal dışlanma teorisidir. Bu teori örgüt içerisindeki kaynakların ve kariyer ilerleme firsatlarının sadece erkek çalışanlar için söz konusu olabileceğini savunmaktadır. Bunun yanında bu teori kadın çalışanların bu imkânlara ulaşmasının nasıl engellendiğini ve örgütten nasıl dışlandıklarını anlatmaktadır. Neredeyse hiçbir organizasyonun misyon ve vizyon ifadesinde cinsiyet çeşitliliği politikasının yer almaması sosyal dışlanma teorisini destekleyen bir durumdur. Bu durumun da çok az sayıda kadın çalışanın orta ve üst yönetim pozisyonunda yer almasına, dolayısıyla diğer kadın çalışanlara rol model olamamalarına ve yönetici adayı kadın çalışanların kişisel ve mesleki rehberlikten mahrum kalmalarına yol açtığı görülmektedir (Sahoo ve Lenka, 2016: 313).

Sosyal dışlanma teorisinin aksine sosyal bilişsel kuram kadın çalışanların üst düzey yönetim pozisyonuna yükselmelerini desteklemektedir. Çünkü sosyal bilişsel teori insanların başkalarının deneyiminden öğrendiğini savunmaktadır. $\mathrm{Bu}$ rol model teorisi, başkalarını gözlemleyerek insanların davranışlarını anlamakta, nasıl davranacaklarını tahmin etmekte ve onların davranışlarını değiştirmektedir. Bu teori, kadın çalışanların üst düzey pozisyonda bulunan rol model kadınları taklit ettiklerinde eğer olumlu bir tepkiyle karşılaşırlarsa bu kadınların davranışlarında bir değişim yani dönüşüm meydana geleceğini ifade etmektedir. Özetle bu teori genç kadın çalışanların; mesleki amaçlarına ulaşmak, iş performanslarını geliştirmek ve başarılı kadın çalışanlara benzemek için çaba harcadıklarını ifade etmektedir (Sahoo ve Lenka, 2016: 313). 
Suyolu teorisi (pipeline) ise kadın çalışanların organizasyon içerisinde kariyer ilerleme firsatlarının olmadıklarını anladıklarında, gönüllü olarak emekli olma yolunu seçtiklerini iddia etmektedir. Bu teori, kadın çalışanların üst yönetim pozisyonlarında görev alma olasılıklarının olmadığını anladıklarında gönüllü olarak emekli olma yolunu seçtiklerini dolayısıyla da daha orta yönetim kademesindeyken işletmeden ayrılmak zorunda kaldıklarını yani işletme tarafından infaz edildiklerini öne sürmektedir. Dolayısıyla bu teori kadın çalışanların bulundukları işletmeden ayrılıp başka işletmelere geçtiklerinde, bulundukları işletmelerde üst yönetim pozisyonlarına gelme şanslarını kaybettikleri iddiasını rasyonelleştirmekte ve bu iddiaları bir mantık çerçevesine oturtmaktadır (Sahoo ve Lenka, 2016: 313).

Bir organizasyonda kadın çalışanın fazlalığı o örgütü sosyal bir topluluk haline getirmektedir. Çünkü kadın çalışanlar duygusal olarak zeki (duygusal zekası yüksek), empati kurabilen, kişilerarası ilişkilere ve güvene önem veren ve samimi ilişkiler geliştirebilen canlı varlıklardır. Kadın çalışanların bu özelliği çalışanların örgüte olan bağlılığını ve çalışanların kararlara katılımını artırmaktadır. Kadın çalışanların sahip olduğu bu üstün özellikler her yönetim kademesinde en azından bir kadın çalışanın bulunmasını kaçınılmaz bir hale getirmektedir (Sahoo ve Lenka, 2016: 313-314).

İnsan kaynakları yönetimi kapsamında; mentorluk, iş yaşam dengesi, kariyer, yedekleme planlaması ve psikolojik destek gibi müdahaleler cinsiyet eşitsizliğini azaltmada kullanılacak yöntemler olabilir. Mentorluk, kadın çalışanları kişisel ve mesleki gelişimleri için motive eden bir araçtır. Üst yönetim pozisyonundaki kadın mentorlar; özsaygıyı ve hesap verilebilirliği geliştirdiği, kadın yönetici olmaya hevesli kadın çalışanlar için psikolojik destek sağladıkları ve yıpranmayı azalttıkları için gerekli görülmektedirler (Sahoo ve Lenka, 2016: 313-314).

Yaşam tarzı ile kariyer arasındaki doğru dengeyi korumak ise iş yaşam dengesidir. Organizasyonlar; bu kapsamda esnek çalışma uygulamaları, iş paylaşımı, çalışan kadınlar için çocuk/yaşlı bakımı sağlama yoluyla inisiyatif alabilmektedirler (Sahoo ve Lenka, 2016: 313-314).

Yedekleme planı kapsamında ise organizasyonlar kilit yönetim pozisyonunda bulunan bir yöneticinin işletmeden herhangi bir nedenle ayrıldığında onun yerini hemen doldurmak ve ehil kadın personeli yetiştirmek için yedekleme planına (halef) ihtiyaç duymaktadırlar (Sahoo ve Lenka, 2016: 314).

\section{Motivasyon}

Güdü, bir kişinin bir uyarıcı ile başlayıp bu uyarana göre davranışlarını değiş̧irmesi ile biten bir hareket etme eğilimidir. Motivasyon ise bir davranışı başlatmanın, sürdürmenin ve bu davranışın yarattığı performansın devam ettirilmesi sürecidir. Bir başka tanıma göre ise motivasyon, bir kişinin bir kurum içerisinde çalışma ve davranış tarzına göre teşvik edilmesi durumudur. Bir başka 
deyişle motivasyon bireysel ihtiyaçları karşılamak ve örgütsel amaçlara ulaşmak için gerekli olan yeteneğin sağlanmasının yanında bu amaçlara ulaşmak için duyulan isteklilik halidir (Daud, 2020: 123-124). Çalışanları iş yapmaya ya da yapmamaya iten özellik olarak da tanımlanan motivasyon; çalı̧̧anların davranışını, amacını ve yönünü belirleyen psikolojik bir süreçtir. Motivasyon örgütün genel çıkarına ulaşmak için çalışanların karşılanmamış ihtiyaçlarını onlara sağlayarak onların daha iyi çalışmasını teşvik eden bir yönetim sürecidir. Motivasyon aynı zamanda amaç odaklı bir davranış aktivasyonudur (Okoth ve Florah, 2019: 21).

Bireyin iç güçlerini, arzularını, isteklerini ve taleplerini ifade eden motivasyonla ilgili literatürde birçok teori bulunmaktadır. Bu teoriler içerisinde beklenti teorisi önde gelen teoriler arasında yer almaktadır. Beklenti teorisi, beklentinin gücüne bağlı olarak çalışanların belirli bir davranış kalıbı içerisinde hareket etmeye mecbur olduklarını varsaymaktadır. Bu teori; çaba ve performans, performans ve ödül ilişkisi, ödül ve kişisel hedef ilişkisi olmak üzere üç temel unsura dayanmaktadır (Okoth ve Florah, 2019: 20).

Beklenti teorisine göre, organizasyonlarda motivasyon analizi yapılabilmesi için içsel ve dışsal olmak üzere iki motivasyon kaynağına ihtiyaç duyulmaktadır (Eliyahu vd., 2020: 255). Bu motivasyon kaynaklarından içsel motivasyon; ilginç bir çalışmayı, terfiyi, kararlara katılımı ve kariyer gelişimi hissini içerirken; dışsal motivasyon kaynakları ise kayda değer bir ücreti, iş güvenliğini, iyi çalışma koşullarını, entelektüel disiplini, promosyonları, sosyal iklimi ve özel dizayn edilmiş ofis alanlarını, liyakat primlerini, izin ve tatillerde yapılan ödemeleri ve işin kendisini içermektedir (Hassoo ve Akbay, 2020: 412413). Öz iradeden kaynaklanan içsel motivasyon diş etkenlerden kaynaklanan dışsal motivasyona göre genellikle daha uzun sürmektedir (Mulyani vd., 2019: 380).

Motivasyonun önde gelen teorileri arasında yer alan bir diğer teori ise amaç teorisidir. Amaç teorisi kendisine zorlayıcı ve belirli hedefler koyan çalışanların bu hedeflerinin etkisiyle dikkatlerinin, çabalarının ve ısrarlarının etkilenebileceğini ve dolayısıyla çalışanların performanslarının artabileceğini ileri sürmektedir (Okoth ve Florah, 2019: 20-21).

Çalışanların motivasyonunu etkileyen önemli teorilerden birisi de çift faktör teorisidir. Çift faktör teorisinin kurucusu Herzberg (1959)'dir. Herzberg (1959) personelin çalışma tutumlarını ve performans düzeylerini belirlemek için hijyen ve motivasyon faktörü olmak üzere iki grup tanımlamıştır. Motivasyon faktörleri personelin iş tatminini artıran içsel faktörlerden oluşurken, hijyen faktörleri herhangi bir çalışanın memnuniyetsizliğini önlemeye yönelik dışsal faktörlerden oluşmaktadır. Herzberg (1959) aynı zamanda hijyen faktörlerinin tam tedarikinin yani varlığının çalışanların iş tatmini ile sonuçlanmayacağını ileri sürmektedir. Çift faktör teorisi Maslow'un ihtiyaçlar hiyerarşisiyle yakından ilgilidir. Ancak çift faktör teorisi bireylerin iş yerinde nasıl motive olduklarını ölçmede Maslow'un ihtiyaçlar hiyerarşisine göre çok daha fazla sayıda faktöre 
sahiptir. Bu teori bireylerin alt düzey ihtiyaçlarının (dışsal ya da hijyen faktörleri) karşılanması durumunda bile çalş̧anların bireysel ve örgütsel amaçları gerçekleştirme konusunda çaba sarf etme yönünde motive edilemeyeceklerini sadece memnuniyetsiz olmalarının önüne geçilebileceğini ileri sürmektedir. Çalışanları motive etmek içinse daha üst düzey ihtiyaçların (içsel ya da motivasyon faktörleri) karşılanması gerektiği bu teoride ileri sürülmektedir. $\mathrm{Bu}$ teoriye göre çalışanlarını motive etmek isteyen kuruluşlar çalışanlarının motivasyonu için içsel ve dişsal motivasyon faktörlerini bir arada bulundurmaya odaklanmalıdırlar (Yusoff vd., 2013: 19).

İnsanları çalışmaya sevk eden faktörleri açıklayan bir başka motivasyon teorisi de eşitlik teorisidir. Eşitlik teorisinin girdi ve çıktı olmak üzere iki yönü bulunmaktadır. Bu teori bir çalışanın kendi işinin girdilerinin çıtılarına oranını başka birinin işinin girdilerinin çıktılarına oranıyla karşılaştırdığında, bu karşılaştırma sonucunda eğer bir eşitsizlik algılarsa bu eşitsizliği düzeltmek için harekete geçeceğini savunmaktadır. Çalışan algıladığı bir eşitsizliği düzeltmek için ya üretkenliğini ya da işinin kalitesini düşürmektedir. Çok kez yaşanan eşitsizliklerin devamsızlığa ve hatta istifalara yol açtığı görülmektedir (AlZawahreh ve Al-Madi, 2012: 158).

Birçok teoriye dayanan motivasyon kavramı; bir kişinin bir amaç için davranışta bulunmasını ve çaba göstermesini, bu davranış ve çabanın ise süreklilik arz etmesini ifade etmektedir. Bir çalışanı somut öğelerle motive etmek önemlidir. Çünkü çalışanların görebildikleri ve aldıkları ödüller onlara değer verildiğini hissettittirmektedir. Çalışanlar sık sık; işin anlamlılığı, iş tercihi, yapılacak iş konusunda yeterli olma ve işte ilerleme imkânları gibi içsel ödüller aramaktadırlar. Thomas (2009) tarafından keşfedilen içsel ödüller psikolog Abraham Maslow'un ihtiyaçlar hiyerarşisine çok benzemektedir. Maslow her kişinin; fizyolojik, güvenlik, aidiyet, sayg1 ve kendini gerçekleştirme gibi ihtiyaçları olduğunu ve bu ihtiyaçları arzuladıklarına inanmaktadır. Maslow tarafından belirlenen bu temel ihtiyaçlar çoğu kişinin bir işte aradığı varsayımlara dayanmaktadır. Bu varsayımlar; çalışanların akıl sağlığı için zararlı olmayan bir iş ortamını, iş güvenliğine sahip güvenli bir alanı, bir amaç duygusunu ve çalışanların kendini değerli hissettikleri bir iş ortamını ifade etmektedir. Maslow'un ihtiyaçlar hiyerarşisinde kabul edilme biçimleri arasında yer alan; tanınma, ödüller ve bir dereceye kadar özgürlük kavramlarını işletme yönetimi çalışanların kendilerini daha iyi hissetmelerine yardımcı olmada ve yaptıkları işte kullanmaktadır (Alhassan ve Greene, 2020: 16-18).

Motivasyon çalışanın iş yapma arzusunu, coşkusunu ve işine karşı duyduğu ilgi derecesini başka bir deyişle çalışanın işine katılım düzeyini ifade etmektedir. Motivasyon çalışanların verimliliklerini artırmak için çalışanların psikolojik düzeydeki ihtiyaçlarını karşılamakta ve çalışanların memnuniyet düzeyini artırmaktadır (Eliyahu vd., 2020: 254-255). Motivasyon amirleri astlaştırmada, zor işleri başarmada ve beklenildiği gibi akıllıca çalışma koşulları yaratmada kullanılabilecek faydalı bir araçtır. Motivasyon bir bireyin içindeki 
gücü; gücün boyutu, yönü ve kişinin iş üzerinde harcadığı çabanın ısrarı ile açılamaktadır (Mulyani vd., 2019: 380-383).

Çalışan motivasyonuna bir bütün olarak bakıldığında, bu bütünün önemli unsurlarından birinin ödül sistemi olduğu söylenebilir. Bütünün bir parçası olan ödül sisteminin bir iş yerinde uygulanması oldukça zordur. Çünkü bazı personel hak etmeden ödül istemektedir. Bu durum bu sorunun özel olarak ele alınmasını gerektirmektedir. Çözülmesi gereken bu sorun çalışan motivasyonuna bireysel yaklaşım için bir neden oluşturmaktadır. Bu yaklaşımın kullanılması işverenler açısından oldukça iyidir. Çünkü bu yaklaşım işverenlerin her bir çalışanının güçlü ve zayıf yönleri ile ilgi alanlarını ölçmesine izin vermektedir (Alhassan ve Greene, 2020: 18). Bu nedenle personel motivasyonuna farklı yaklaşılmalı, organizasyondaki her bir üyenin bireyselliği, potansiyeli, ihtiyaçları, ilgi alanları, davranışları, hırsları ve yeni sorumluluk üstlenme arzusu göz önünde bulundurulmalıdır. Motivasyon kavramı personelin bireysel ihtiyaçlarını karşılarken, örgütün amaçlarını gerçekleştirmek için çabalaması anlamına gelmektedir. Bu tanıma göre motivasyonun; ihtiyaç, çaba ve hedef olmak üzere üç ana koordinatı bulunmaktadır. Ayrıca bir çalışanın motivasyonunun bir şirketin sürdürülebilirliği açısından oldukça önemli bir unsur olduğu söylenebilir (Panait, 2020: 116).

Çalışanların motivasyonu örgütsel yönetim için her zaman bir endişe kaynağ 1 olmuştur. Çünkü çalışanlar mikro yönetimden şüphelendikleri zaman, şirketlerinden ayrılmaktadırlar. Böyle bir durumda onları örgüt içerisinde tutabilecek tek ajan motivasyondur. Bu nedenle personelin çok çalışması ve örgütte tutulabilmesi için böyle değerli bir teşviğe ihtiyaç duyulmaktadır (Alhassan ve Greene, 2020: 18).

İşverenler çalışanlarına sunduğu yaşam sigortasından çocuk bakım ve yardım kuponlarına, ücretli izine, teşvik seyahatine, mülk sahibi olmaya, olaylara ve tanımlama sistemlerine kadar değişik fayda araçlarıyla çalışanlarını motive edebilmektedirler. Ayrıca işverenler şirket kültürünün bir parçası olarak ödüllendirme ve kararlara katılım gibi teşvik programları ile de çalışanlarının motive olmasını sağlayabilmektedirler (Alhassan ve Greene, 2020: 19). Personelin unvanındaki değişim ve çalışanların işlerine bağlı kalmaları için daha çok memnun edilmeleri de yine işverenler tarafından kullanılabilecek bir motivasyon uygulamalarıdır. Bu uygulamaları hayata geçirebilen bir örgüt bu yöntemlerle personelinin motivasyon seviyesini etkileyebilecek, kontrol mekanizması için personelin motivasyonunu yüksek düzeyde tutacak ve örgütsel kültürü geliştirebilecektir (Daud, 2020: 123). Örgütler bu motivasyon araçlarını kullanarak çalışanlarını belirli bir hedefe doğru kanalize edecek ve bu sayede örgütün rakipleri üzerinde bir rekabet avantajı kazanmasını sağlayacaktır (Okoth ve Florah, 2019: 21).

Motive olmuş insanlarla çalışmanın örgüte kazandırdı̆̆ 1 birtakım avantajlar bulunmaktadır. Motive olmuş insanlar zevkle çalışacaklar, takdir edildiklerini hissettikleri anda ise bu durum hemen onların performansına 
yansıyacaktır. Motivasyon sayesinde çalışanların sahip olduğu yüksek moral mükemmel bir çalışma ortamı sağlayacaktır. Ayrıca elde edilen sonuçlar tüm çalışanlar tarafından izlenerek değerlendirilecek dolayısıyla da çok fazla denetime gerek kalmayacaktır. Motive olmuş çalışanlar iyi sonuç elde etmek isteyecek ve bu nedenle de daha çok ve daha dikkatli çalışacaklardır. Motivasyon sayesinde çalışanlar kuruma karşı olumlu tutum sergileyeceklerdir. Personel devir ve devamsızlık oranı azalacaktır. Çalışanlar tarafından yaratııılık ve sorumluluk alma düzeyi artacaktır. Çalışanların motive olması önemli olduğu kadar, çalışanların motive olmasını sağlayan koşulların sürdürülmesi çok daha önemli olmaktadır. Bu nedenle motivasyonu sağlayan koşulları korumak sürekli bir dikkat gerektirecektir. Çalışanlar için en önemli motivasyon faktörü mesleki faaliyete anlam veren amaçtır. $\mathrm{Bu}$ amaç çekici olmalı, aynı zamanda tüm çalışanları ortak bir yöne yönlendirmeli ve çalışanların duyguları ile kararlarına hitap eder nitelikte olmalidır (Panait, 2020: 118-119).

\section{Araştırmanın Metodolojisi}

Lojistik sektöründe çalışan kadınların cam tavan algılarının motivasyon ile olan ilişkisinin incelendiği bu bölümde araştırmada kullanılan yönteme ilişkin bilgilere yer verilmektedir. Araştırmanın bu bölümünde; araştırmanın amacına, örneklemine, araştırmada kullanılan ölçeklere, araştırmanın kavramsal modeline, geliştirilen hipotezlere ve verilerin analizine ilişkin bulgulara yer verilmektedir.

\subsection{Araştırmanın Amacı ve Önemi}

Araştırmanın amacı, lojistik sektöründe çalışan kadınların cam tavan algılarının motivasyon ile olan ilişkisini ortaya koymaktır. Bu çalışma ile karar alıcıların kadın çalışanların başarıya ulaşmalarını engelleyecek hayali duvarlara, bu hayali duvarların yarattığı olumsuz sonuçlardan biri olan motivasyon kaybına ve bu iki değişken arasındaki ilişkinin varlığına dikkatlerinin çekilmesi amaçlanmaktadır. Ayrıca bu çalışma cinsiyet ayrımcılığının neden olduğu cam tavan sendromunun motivasyon üzerindeki etkilerini ortaya koymakta ve bu duruma yönelik çözüm önerileri geliştirmekte ve sektörün ivmelenmesine bir miktar da olsa katkı sunmaktadır. Gelecekte arzulanan sonuçlara ulaşmak isteyen işletmeler için cam tavan algısını ortadan kaldırmanın dolayısıyla çalışan motivasyonunu artırmanın başka bir deyişle insan kaynağından etkin bir şekilde yararlanmak isteyen işletmelerin böyle bir tercihte bulunmalarının etkin bir yöntem olabileceği konusunda karar alıcılarda bir farkındalık yaratmak da bu çalışmanın amaçları arasında yer almaktadır.

\subsection{Araștırmanın Evreni ve Örneklemi}

Araştırmanın evrenini, Mersin ilinde faaliyet gösteren lojistik firmalarında çalışan beyaz yakalı personeller oluşturmaktadır. Örneklemini ise Mersin ilinde faaliyet gösteren lojistik firmalarında çalışan beyaz yakalı kadın çalışanlar oluşturmaktadır. Mersin ilinin Türkiye' de bulunan dört büyük lojistik kentten bir olması ve gerek ulusal gerekse uluslararası ölçekteki hemen hemen tüm Lojistik 
firmaların şube ve temsilciliklerine ev sahipliği yapması Mersin ilinin araştırmanın örneklemi olarak seçilmesinde oldukça etkili olmuştur. Ayrıca Mersin Limanı konteyner işlem hacmiyle Türkiye'de birinci sırada yer almaktadır (MIP, 2018). Mersin limanının bu özelliklerinden dolayı Mersin'de dünyaca tanınmış, marka değeri yüksek büyük kurumsal lojistik sağlayıcılar faaliyet göstermektedir. Mersin ilinin bu özellikleri Mersin ilinin araştırmanın örneklemi olarak seçilmesinde oldukça etkili olmuştur. Ayrıca Mersinin ilinin önemli bir lojistik kent olması sebebiyle burada yapılan çalışmanın sonuçlarının sektör temsilcilerine önemli katkılar sunacağı ve çalışmanın sonuçlarının genelleştirilebileceği düşünülmüş ve bu sebeplerden dolayı araştırmanın örneklemi Mersin ilinde faaliyet gösteren lojistik firmalarında çalışan beyaz yakalı kadın çalışanlar olarak belirlenmiştir. Araştırmada olasılıklı olmayan örnekleme yöntemlerinden amaçlı örnekleme yöntemi kullanılarak Utikad'ın (Uluslararası Taşımacılık ve Lojistik Hizmet Üretenleri Derneği) Mersin şubesine kayıtlı lojistik firmalarında çalışan 100 beyaz yakalı kadın çalışandan tam sayım yöntemi ile elektronik ortamda veri elde edilmiştir. Ancak hatalı doldurulan 5 anket değerlendirme dışı bırakılarak sadece 95 anket değerlendirme kapsamına alınmıştır.

\subsection{Veri Toplama Aracl}

Araştırmada kullanılan anket üç bölümden oluşmaktadır. Anketin birinci bölümü; yaş, medeni durum, çalışma pozisyonu, aylık gelir, eğitim düzeyi ve iş deneyimi olmak üzere altı demografik sorudan oluşmaktadır.

Anketin ikinci bölümü ise Irmak ve Budak (2010) tarafından geliştirilen cam tavan sendromu ölçeğinden meydana gelmektedir. 5'li Likert tipinde sorular içeren cam tavan ölçeğinde '1. Kesinlikle Katılmıyorum', '2. Katılmıyorum', '3. Kararsızım', '4. Katıliyorum' ve '5. Kesinlikle Katılıyorum' ifadelerini içermektedir. $\mathrm{Bu}$ ölçeğin; üst yönetimden kaynaklanan engeller, kadınlara yönelik olumsuz önyargılar, aile hayatı, cinsiyet ayrımcılığı, mesleki ayrım, örgüt kültürü ve politikalar, informal iletişim ağları, kadınların kariyer basamaklarında yükselmelerindeki etkenler ve mentorluk olmak üzere dokuz alt boyutu bulunmaktadır.

Anketin üçüncü bölümünde ise Mottaz (1985) tarafından geliştirilen Ertan ve Ağca (2008)'nın “Örgütsel Bağlılık, İş Motivasyonu ve İş Performansı Arasındaki İlişki: Antalya'da Beş Yıldızlı Otel İşletmelerinde Bir İnceleme" başlıklı doktora tezinde kullandıkları iş motivasyon ölçeği kullanılmıştır. 5'li Likert tipinde sorular içeren iş motivasyonu ölçeğinde ' 1 . Kesinlikle Kat1lmiyorum', '2. Katılmiyorum', '3. Fikrim Yok', '4. Kat1lyyorum' ve '5. Kesinlikle Katılıyorum' ifadelerini içermektedir. Bu ölçek içsel ve dışsal motivasyon olmak üzere iki alt boyut içermektedir.

\subsection{Araştırmanın Modeli ve Hipotezleri}

Araştırma kapsamında tarama modeli kullanılmış olup araştırmanın kavramsal modeli Şekil 1'de ifade edilmiştir. Bu modele göre, araştırmanın 
bağımsız değişkeni cam tavan algısı, alt bağımsız değişkenleri ise üst yönetimden kaynaklanan engeller, kadınlara yönelik olumsuz önyargılar, aile hayatı, cinsiyet ayrımcılığı, mesleki ayrım, örgüt kültürü ve politikalar, informal iletişim ağları ve kadınların kariyer basamaklarında yükselmelerindeki etkenlerdir. Araştırmanın bağımlı değişkeni motivasyon, alt bağımlı değişkenleri ise içsel motivasyon ile dışsal motivasyondur.

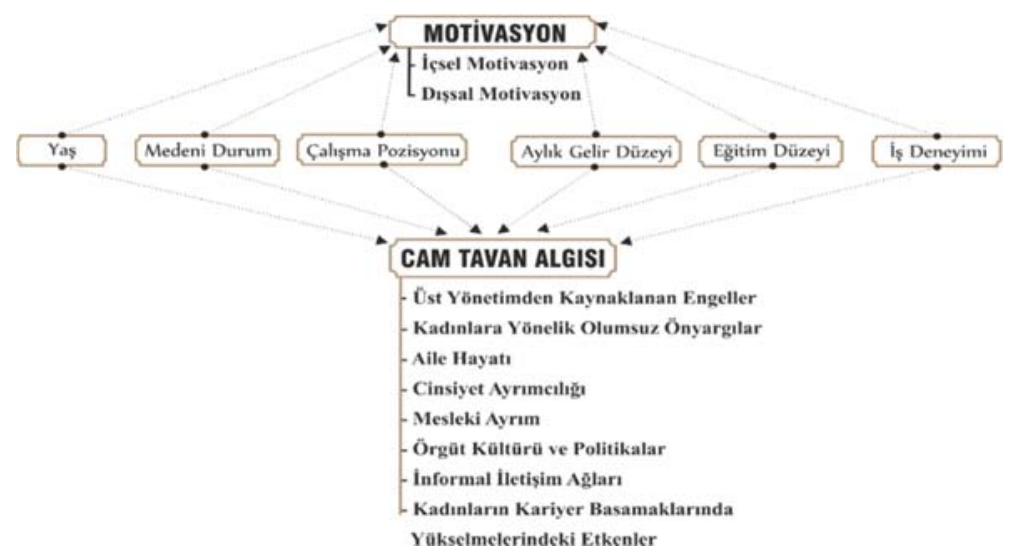

Şekil 1. Araştırmanın Kavramsal Modeli

Çalışmada, araştırmanın amacı doğrultusunda bağımlı ve bağımsız değişkenler kullanılarak 6 hipotez ileri sürülmüştür.

$\mathbf{H}_{1 \mathbf{a}}$ : Cam tavan algısı ile motivasyon arasında anlamlı bir ilişki vardır. vardir.

$\mathbf{H}_{\mathbf{1}}$ : Cam tavan algısı ile içsel motivasyon arasında anlamlı bir ilişki vardir.

H1c: Cam tavan algısı ile dışsal motivasyon arasında anlamlı bir ilişki

$\mathbf{H}_{1 \mathrm{~d}}$ : Cam tavan boyutlarının motivasyon üzerinde anlamlı bir etkisi vardir. vardir.

$\mathbf{H}_{1 \mathrm{e}}$ : Cam tavan boyutlarının içsel motivasyon üzerinde anlamlı bir etkisi etkisi vardır.

$\mathbf{H}_{1 \mathbf{f}}$ : Cam tavan boyutlarının dışsal motivasyon üzerinde anlamlı bir

\subsection{Araştırmanın Veri Çözümleme Yöntemleri}

\subsubsection{Frekans Analizi}

Tablo 1'de örneklemdeki çalışanlara ait betimleyici istatistikler yer almakta ancak araştırma konusunun özelliği gereğince sadece kadın çalışanlara uygulanması gerektiğinden bu istatistikler içerisinde cinsiyet değerlendirmesi bulunmamaktadır. Tabloda yer alan sonuçlara göre; örneklemde $\% 55,8$ 'lik bir çoğunlukla 26-35 yaş aralığında genç çalışanlar yer almaktadır. Araştırmaya katılan kadın çalışanların \%86,3'ünün üniversite mezunu olduğu, \%62,1'lik 
çoğunluğunun ise bekâr olduğu görülmektedir. Katılımcılar çalışma süresi açısından incelendiğinde ise örneklemdeki kadın çalışanların \%79'unun 1 yıldan daha fazla bir çalışma deneyimine sahip olduğu belirlenmiştir.

Tablo 1: Betimleyici İstatistikler - 1

\begin{tabular}{|c|c|c|c|}
\hline & Frekans & $\begin{array}{l}\text { Yüzde } \\
\text { Oranı }\end{array}$ & Kümülatif Yüzde \\
\hline \multicolumn{4}{|l|}{ Yaş } \\
\hline 25 ve altı & 22 & $\% 23,1$ & $\% 23,1$ \\
\hline $26-35$ & 53 & $\% 55,8$ & $\% 78,9$ \\
\hline $36-45$ & 14 & $\% 14,7$ & $\% 93,6$ \\
\hline $46-55$ & 5 & $\% 5,3$ & $\% 98,9$ \\
\hline 56 ve üstü & 1 & $\% 1,1$ & $\% 100,0$ \\
\hline \multicolumn{4}{|c|}{ Eğitim Durumu } \\
\hline Lise & 13 & $\% 13,7$ & $\% 13,7$ \\
\hline Yüksekokul & 13 & $\% 13,7$ & $\% 27,4$ \\
\hline Lisans & 45 & $\% 47,3$ & $\% 74,7$ \\
\hline Yüksek Lisans & 22 & $\% 23,2$ & $\% 97,9$ \\
\hline Doktora & 2 & $\% 2,1$ & $\% 100,0$ \\
\hline \multicolumn{4}{|c|}{ Medeni Durum } \\
\hline Evli & 36 & $\% 37,9$ & $\% 37,9$ \\
\hline Bekâr & 59 & $\% 62,1$ & $\% 100,0$ \\
\hline \multicolumn{4}{|l|}{ Çalışma Süresi } \\
\hline 1 yıldan az & 20 & $\% 21,0$ & $\% 21,0$ \\
\hline $1-5$ y1l & 43 & $\% 45,2$ & $\% 66,2$ \\
\hline $6-10$ y1l & 19 & $\% 20,0$ & $\% 86,2$ \\
\hline $11-15 \mathrm{y} 1 \mathrm{l}$ & 5 & $\% 5,3$ & $\% 91,5$ \\
\hline $16-20$ yil & 5 & $\% 5,3$ & $\% 96,8$ \\
\hline 21 yıl ve üzeri & 3 & $\% 3,2$ & $\% 100,0$ \\
\hline
\end{tabular}

Tablo 2'de araştırmaya katılan çalışanlara yönelik betimleyici istatistiklerin devamı görülmektedir. Örneklemdeki çalışanların aylık gelir durumu incelendiğinde, aylık gelirin hemen hemen homojen bir dağılım gösterdiği, herhangi bir gelir aralığına ilişkin baskınlığın olmadığı saptanmıştır. Bununla birlikte asgari ücret düzeyinde ve daha düşük düzeyde aylık gelire sahip çalışan oranının \%36,8 olduğu belirlenmiştir. Katılımcılar çalışma pozisyonu açısından değerlendirildiğinde ise kadın çalışanların \%30,5'inin memur, $\% 20$ 'sinin yönetici, \%16,8'inin işçi, geriye kalanların ise çeşitli departmanlarda görev yaptı̆̆ 1 tespit edilmiştir. 
Lojistik Sektöründe Çalışan Kadınların Motivasyonlarının Cam Tavan Algıları Açısından Değerlendirilmesi

Tablo 1: Betimleyici İstatistikler - 2

\begin{tabular}{|c|c|c|c|}
\hline & Frekans & $\begin{array}{l}\text { Yüzde } \\
\text { Oranı }\end{array}$ & Kümülatif Yüzde \\
\hline \multicolumn{4}{|l|}{ Aylık Gelir Durumu } \\
\hline 1500 TL ve daha az & 14 & $\% 14,7$ & $\% 14,7$ \\
\hline $1501 \mathrm{TL}-2000 \mathrm{TL}$ & 21 & $\% 22,1$ & $\% 36,8$ \\
\hline $2001 \mathrm{TL}-3000 \mathrm{TL}$ & 23 & $\% 24,2$ & $\% 61,0$ \\
\hline $3001 \mathrm{TL}-4000 \mathrm{TL}$ & 20 & $\% 21,1$ & $\% 82,1$ \\
\hline 4001 TL ve üzeri & 17 & $\% 17,9$ & $\% 100,0$ \\
\hline \multicolumn{4}{|l|}{ Çalışma Pozisyonu } \\
\hline Yönetici & 19 & $\% 20,0$ & $\% 20,0$ \\
\hline $\begin{array}{l}\text { Yurtiçi Lojistik } \\
\text { Operasyon Elemanı }\end{array}$ & 7 & $\% 7,3$ & $\% 27,3$ \\
\hline $\begin{array}{l}\text { Yurtdışı Lojistik } \\
\text { Operasyon Elemanı }\end{array}$ & 3 & $\% 3,2$ & $\% 30,5$ \\
\hline Dokümantasyon Elemanı & 5 & $\% 5,2$ & $\% 35,7$ \\
\hline Memur & 29 & $\% 30,5$ & $\% 66,2$ \\
\hline Şef & 3 & $\% 3,2$ & $\% 69,4$ \\
\hline Yurtiçi Satış Elemanı & 3 & $\% 3,2$ & $\% 72,6$ \\
\hline Yurtdışı Satış Elemanı & 3 & $\% 3,2$ & $\% 75,8$ \\
\hline Fiyatlandırma Elemanı & 4 & $\% 4,2$ & $\% 80,0$ \\
\hline İşçi & 16 & $\% 16,8$ & $\% 96,8$ \\
\hline Diğer & 3 & $\% 3,2$ & $\% 100,0$ \\
\hline
\end{tabular}

4.5.2. Geçerlik ve Güvenirlik Analizi

Araştırmada kullanılan ölçeklerin yapı geçerliğinin tespiti için Doğrulayıcı Faktör Analizi (DFA) yapılmıştır. Doğrulayıcı faktör analizi sonucunda elde edilen önerilen uyum değerleri Tablo 3'te, standardize edilmiş çözüm değerleri ise Şekil 2' de verilmektedir.

Tablo 3: Motivasyon Ölçeği / Önerilen Uyum Değerleri

\begin{tabular}{|c|c|c|c|c|c|c|c|c|c|}
\hline $\begin{array}{l}\text { Uyum } \\
\text { Kriteri }\end{array}$ & $\chi^{2}$ & $\mathrm{P}$ & $\chi^{2} / \mathrm{df}$ & RMSEA & CFI & IFI & SRMR & NFI & GFI \\
\hline $\begin{array}{l}\text { Önerilen } \\
\text { Uyum } \\
\text { Değerleri }\end{array}$ & 242,964 & 0,000 & 1,568 & 0,07 & 0,921 & 0,923 & 0,07 & 0,813 & 0,820 \\
\hline
\end{tabular}




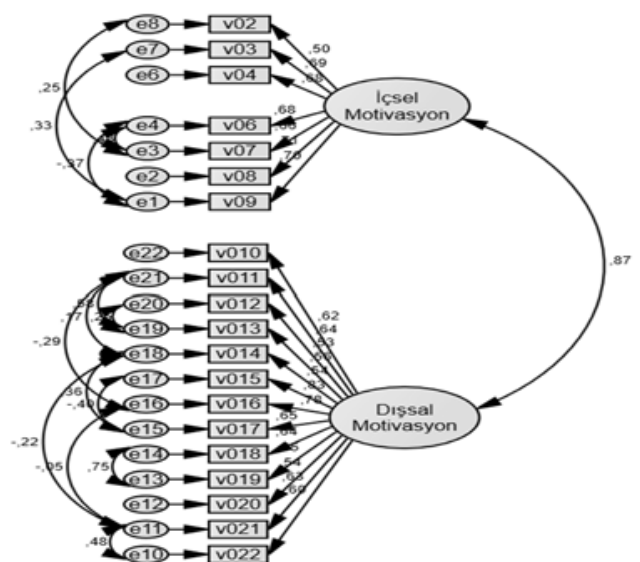

Şekil 2: Motivasyon Ölçeği / Standardize Edilmiş Çözümleme Değerleri

Cam tavan ölçeğine yönelik gerçekleştirilen Doğrulayıcı Faktör Analizi (DFA) sonucunda elde edilen önerilen uyum değerleri Tablo 4'te, standardize edilmiş çözüm değerleri ise Şekil 3' te verilmektedir.

Tablo 4: Cam Tavan Ölçeği / Önerilen Uyum Değerleri

\begin{tabular}{lccccccccc}
\hline $\begin{array}{l}\text { Uyum } \\
\text { Kriteri }\end{array}$ & $\chi^{2}$ & $\mathrm{P}$ & $\chi^{2} / \mathrm{df}$ & RMSEA & CFI & IFI & SRMR & NFI & GFI \\
\hline $\begin{array}{l}\text { Önerilen } \\
\text { Uyum } \\
\text { Değerleri }\end{array}$ & 294,182 & 0,001 & 1,325 & 0,05 & 0,915 & 0,920 & 0,08 & 0,739 & 0,814 \\
\hline
\end{tabular}

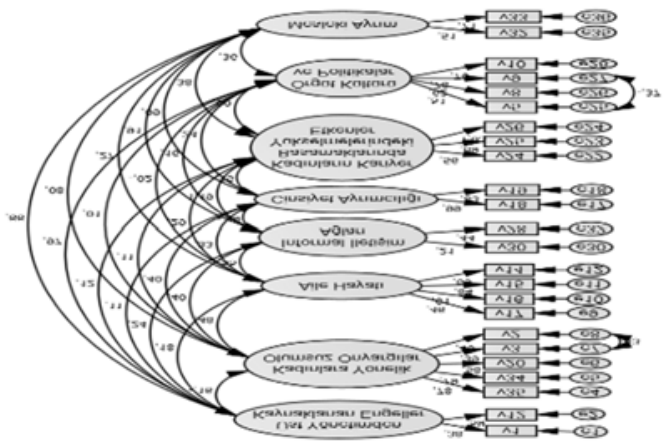

Şekil 1: Cam Tavan Ölçeği / Standardize Edilmiş Çözümleme Değerleri

Tablo 3'te ifade edilen motivasyon ölçeğine ait önerilen uyum değerleri ile Tablo 4'te ifade edilen cam tavan ölçeğine ait önerilen uyum değerlerinin Schermelleh-Engel ve diğerleri (2003) tarafindan yayımlanan uyum iyiliği istatistiklerine uygun olduğu ve araştırmada kullanılan ölçeklerin yapı geçerliğinin kabul edilebilir düzeyde olduğu saptanmıştır. 
Lojistik Sektöründe Çalışan Kadınların Motivasyonlarının Cam Tavan Algıları Açısından Değerlendirilmesi

Yapısal geçerliliği sağlanan bu ölçeklere yönelik güvenirlik analizi yapılmış ve güvenirlik analizinin sonuçları Tablo 5 'te ifade edilmiştir.

Tablo 5: Güvenirlik Analizi

\begin{tabular}{lcc}
\hline & Cronbach's Alpha & N of Items \\
\hline Motivasyon Ölçeği & 0.926 & 20 \\
\hline$*$ İçsel Motivasyon & 0.848 & 7 \\
\hline * Dişsal Motivasyon & 0.899 & 13 \\
\hline Cam Tavan Ölçeği & 0.751 & 24 \\
\hline * Üst Yönetimden Kaynaklanan Engeller & 0.331 & 2 \\
\hline * Kadınlara Yönelik Olumsuz Önyargılar & 0.726 & 5 \\
\hline * Aile Hayatı & 0.719 & 4 \\
\hline * Cinsiyet Ayrımcılığı & 0.890 & 2 \\
\hline * Mesleki Ayrım & 0.482 & 2 \\
\hline$*$ Örgüt Kültürü ve Politikalar & 0.711 & 4 \\
\hline * İnformal İletişim Ağları & 0.010 & 2 \\
\hline *Kadınların Kariyer Basamaklarında & 0.814 & 3 \\
Yükselmelerindeki Etkenler & & \\
\hline
\end{tabular}

Tablodan da görüldüğü üzere cam tavan ölçeğinin informal iletişim ağları boyutu için Cronbach's Alpha katsayısı 0.010, üst yönetimden kaynaklanan engeller boyutu için 0.331 , mesleki ayrım boyutu için ise 0.482 olarak belirlenmiş ve bu boyutların iç tutarlılığa sahip olmadığı tespit edilmiştir. Bu nedenle ileri istatistiksel analizlerde bu boyutlar değerlendirme dışı bırakılmıştır.

\subsubsection{Normallik Analizi}

Araştırma kapsamında elde edilen verilere yönelik gerçekleştirilen normallik testi sonucunda saptanan Kolmogorov-Smirnov ve Shapiro-Wilk değerleri Tablo 6' da ifade edilmiştir.

Tablo 6: Normallik Test Sonuçları

\begin{tabular}{l|ccc|ccc} 
& \multicolumn{3}{c}{ Kolmogorov-Smirnov } & \multicolumn{3}{c}{ Shapiro-Wilk } \\
\cline { 2 - 7 } & Statistic & df & Sig. & Statistic & Df & Sig. \\
\hline Motivasyon & 0.045 & 95 & 0.200 & 0.980 & 95 & 0.161 \\
* İçsel Motivasyon & 0.080 & 95 & 0.163 & 0.962 & 95 & 0.008 \\
* Dişsal Motivasyon & 0.058 & 95 & 0.200 & 0.987 & 95 & 0.478 \\
\hline Cam Tavan & 0.082 & 95 & 0.128 & 0.959 & 95 & 0.005 \\
* Kadınlara Yönelik Olumsuz Önyargılary & 0.101 & 95 & 0.018 & 0.958 & 95 & 0.004 \\
* Cinsiyet Ayrımcılığı & 0.254 & 95 & 0.000 & 0.896 & 95 & 0.000 \\
* Aile Hayatı & 0.087 & 95 & 0.072 & 0.978 & 95 & 0.109 \\
* Örgüt Kültürü ve Politikalar & 0.089 & 95 & 0.063 & 0.981 & 95 & 0.194 \\
* Kadınların Kariyer Basamaklarında & 0.223 & 95 & 0.000 & 0.877 & 95 & 0.000 \\
Yükselmelerindeki Etkenler & & & & & \\
\hline
\end{tabular}

Örneklem büyüklüğü nedeniyle Tablo 6'da yer alan Kolmogorov-Smirnov değerleri dikkate alındığında; bütünleşik olarak motivasyon ölçeğinden ve bu ölçeğin alt boyutlarından elde edilen verilerin normal dağılım gösterdiği 
görülmektedir. Cam tavan ölçeği incelendiğinde ise; ölçeğin genelinin ve bu ölçeğin aile hayatı boyutu ile örgüt kültürü ve politikalar boyutundan elde edilen verilerin normal dağılım gösterdiği görülmektedir. Kolmogorov-Smirnov analizine göre normal dağılım göstermeyen; cinsiyet ayrımcıllı̆̆, kadınlara yönelik olumsuz önyargılar ve kadıların kariyer basamaklarında yükselmelerindeki etkenler boyutlarına ilişkin kurtosis (basıklık) ve skewness (çarpıklık) değerleri Tablo 7'de detaylandırılmıştır. George ve Mallery (2003)'nin sinıflandırmasına göre bu boyutlardan elde edilen verilere ait basıklık ve çarpıklık değerlerinin -2 ile +2 aralığında olduğu, bu nedenle de ilgili ölçek boyutlarının da normal dağılım gösterdiği belirlenmiştir.

Tablo 7: Normallik Testine Ait Betimleyici Istatistikler

\begin{tabular}{llcc} 
& & Statistic & Std. Error \\
\hline \multirow{2}{*}{ Cinsiyet Ayrımcılığ } & Skewness & -0.562 & 0.247 \\
& Kurtosis & -0.260 & 0.490 \\
\hline \multirow{2}{*}{ Kadınlara Yönelik Olumsuz Önyargılar } & Skewness & 0.530 & 0.247 \\
& Kurtosis & -0.008 & 0.490 \\
\hline * Kadınların Kariyer Basamaklarında & Skewness & -1.125 & 0.247 \\
Yükselmelerindeki Etkenler & Kurtosis & 1.542 & 0.490 \\
\hline
\end{tabular}

\subsubsection{Korelasyon Analizi}

Tablo 8'de araştırmanın değişkenleri arasındaki korelasyon analizi sonuçları görülmektedir. Bu tabloya göre; cam tavan algısı ile motivasyon ve motivasyonun dışsal boyutu arasında negatif yönde ve düşük düzeyde anlamlı bir ilişki olduğu saptanmıştır. Cam tavan algısı ile içsel motivasyon arasında ise istatistiksel olarak hiçbir ilişkiye rastlanmamıştır. Cam tavan algısının alt boyutları incelendiğinde ise cam tavan algısının; cinsiyet ayrımcılı̆̆ı, aile hayatı, örgüt kültürü ve politikalar alt boyutları ile motivasyon arasında negatif yönde ve düşük düzeyde anlamlı bir ilişki olduğu tespit edilmiştir.

Tablo 8: Korelasyon Analizi Sonuçları

\begin{tabular}{|c|c|c|c|c|}
\hline & & Motivasyon & \begin{tabular}{|c|} 
İçsel \\
Motivasyon
\end{tabular} & $\begin{array}{c}\text { Dişsal } \\
\text { Motivasyon }\end{array}$ \\
\hline \multirow{2}{*}{ Cam Tavan Algisı } & Pearson Cor. & -0.216 & -0.141 & -0.226 \\
\hline & Sig. (2-tailed) & $0.036^{*}$ & $0.172^{* *}$ & $0.028^{*}$ \\
\hline \multirow{2}{*}{$\begin{array}{l}\text { - Kadınlara Yönelik Olumsuz } \\
\text { Önyargılar }\end{array}$} & Pearson Cor. & -0.055 & 0.154 & 0.015 \\
\hline & Sig. (2-tailed) & $0.597^{* *}$ & $0.135^{* *}$ & $0.888^{* *}$ \\
\hline \multirow{2}{*}{ - Cinsiyet Ayrımcılığı } & Pearson Cor. & 0.223 & -0.164 & -0.220 \\
\hline & Sig. (2-tailed) & $0.030^{*}$ & $0.112^{* *}$ & $0.032^{*}$ \\
\hline \multirow{2}{*}{ - Aile Hayatı } & Pearson Cor. & -0.221 & 0.170 & 0.217 \\
\hline & Sig. (2-tailed) & $0.032^{*}$ & $0.100^{* *}$ & $0.035^{*}$ \\
\hline \multirow{2}{*}{ - Örgüt Kültürü ve Politikalar } & Pearson Cor. & -0.368 & 0.298 & 0.361 \\
\hline & Sig. (2-tailed) & $0.000^{*}$ & $0.003^{*}$ & $0.000^{*}$ \\
\hline - Kadınların Kariyer Basamaklarında & Pearson Cor. & 0.175 & -0.227 & -0.141 \\
\hline Yükselmelerindeki Etkenler & Sig. (2-tailed) & $0.090^{* *}$ & $0.027^{*}$ & $0.173^{* *}$ \\
\hline
\end{tabular}


Lojistik Sektöründe Çalışan Kadınların Motivasyonlarının Cam Tavan Algıları Açısından Değerlendirilmesi

Gerçekleştirilen korelasyon analizi sonucunda içsel motivasyon ile cam tavan algısının alt boyutları incelendiğinde; örgüt kültürü ve politikalar boyutu ile içsel motivasyon boyutu arasında pozitif yönde ve düşük düzeyde, kadınların kariyer basamaklarında yükselmelerindeki etkenler boyutu ile içsel motivasyon boyutu arasında ise negatif yönde ve düşük düzeyde anlamlı ilişki olduğu tespit edilmiştir. Dışsal motivasyon ile cam tavan algısının alt boyutları incelendiğginde ise aile hayatı ile örgüt kültürü ve politikalar boyutlarıyla dışsal motivasyon arasında pozitif yönde ve düşük düzeyde, cinsiyet ayrımcılığı ile dışsal motivasyon arasında ise negatif yönde ve düşük düzeyde anlamlı bir ilişki olduğu saptanmıştır.

\subsubsection{Regresyon Analizi}

Tablo 9'da motivasyon ile cam tavan algısının alt boyutlarına yönelik çoklu regresyon analizinin ANOVA sonuçları görülmektedir. Gerçekleştirilen regresyon analizi sonucunda; oluşturulan modelin anlamll1ık değerinin 0.05 'ten küçük olması nedeniyle modelin istatistiksel olarak anlamlılık ifade ettiği saptanmıştır.

Tablo 9: Motivasyon \& Cam Tavan Algisl - ANOVA

\begin{tabular}{|c|c|c|c|c|c|}
\hline \multirow{4}{*}{ Motivasyon } & \multicolumn{2}{|c|}{ Sum of Squares } & \multirow{2}{*}{$\begin{array}{c}\text { Mean Square } \\
664.975\end{array}$} & \multirow[t]{2}{*}{$\mathrm{F}$} & \multirow[t]{2}{*}{ Sig. } \\
\hline & Regression & 3324.873 & & & \\
\hline & Residual & 11338.116 & 127.395 & 5.220 & 0.000 \\
\hline & Toplam & 14662.989 & & & \\
\hline
\end{tabular}

Enter yöntemiyle gerçekleştirilen çoklu regresyon analizinin sonuçları Tablo 10'da ifade edilmiştir.

Tablo 10: Motivasyon \& Cam Tavan Algisl-Model

\begin{tabular}{|c|c|c|c|c|c|c|}
\hline \multirow{7}{*}{ Motivasyon } & Cam Tavan Algisı & $\beta$ & $\mathrm{t}$ & Sig. & $\mathrm{R}^{2}$ & $\begin{array}{c}\text { Adjusted } \\
\mathrm{R}^{2}\end{array}$ \\
\hline & Constant & 32.905 & 3.252 & 0.002 & \multirow{6}{*}{0.277} & \multirow{6}{*}{0.183} \\
\hline & Kadınlara Yönelik & -0.244 & -0.717 & 0.475 & & \\
\hline & Aile Hayatı & 0.921 & 2.548 & 0.013 & & \\
\hline & Cinsiyet Ayrımcilığ & -0.170 & -0.243 & 0.809 & & \\
\hline & $\begin{array}{l}\text { Örgüt Kültürü ve } \\
\text { Politikalar }\end{array}$ & 1.258 & 3.691 & 0.000 & & \\
\hline & $\begin{array}{l}\text { Kadınların Kariyer } \\
\text { Basamaklarında } \\
\text { Yükselmelerindeki } \\
\text { Etkenler }\end{array}$ & -0.961 & -2.015 & 0.047 & & \\
\hline
\end{tabular}

$\mathrm{Bu}$ tablo incelendiğinde; motivasyondaki değişimin \%18,3'ünü cam tavan algısının üç alt boyutundaki değişimin açıkladığı saptanmıştır. Bu sonuçlara göre motivasyonun alabileceği değer aşağıdaki şekilde formüle edilmiştir; 
"Motivasyon $=32.905+(0.921 \times$ Aile Hayat1 $)+(1.258$ x Örgüt Kültürü ve Politikalar) - (0.961 x Kadınların Kariyer Basamaklarında Yükselmelerindeki Etkenler)"

Regresyon analizi sonucunda elde edilen formüle göre; cam tavan algisının aile hayatı boyutundaki 1 birimlik artışın motivasyon üzerinde 0.921 birimlik bir artışa, örgüt kültürü ve politikalar boyutundaki 1 birimlik artışın motivasyon üzerinde 1.258 birimlik bir artışa, kadınların kariyer basamaklarında yükselmelerindeki etkenler boyutundaki 1 birimlik artışın ise motivasyon üzerinde 0.961 birimlik bir azalışa neden olduğu belirlenmiştir. Kadınlara yönelik olumsuz önyargılar ile cinsiyet ayrımcıllğı boyutlarının ise diğer cam tavan algısı boyutlarıyla birlikte değerlendirildiğinde motivasyon üzerinde anlamlı bir etkisinin olmadığı saptanmıştır.

Tablo 11'de motivasyonun içsel boyutu ile cam tavan algısının boyutlarına yönelik çoklu regresyon analizinin ANOVA sonuçları görülmektedir. Gerçekleştirilen regresyon analizi sonucunda; oluşturulan modelin anlamll1ık değerinin 0.05 'ten küçük olması nedeniyle modelin istatistiksel olarak anlamlılık ifade ettiği saptanmıştır.

Tablo 11: İçsel Motivasyon \& Cam Tavan Algisl- ANOVA

\begin{tabular}{|c|c|c|c|c|c|}
\hline \multirow{4}{*}{ İçsel Motivasyon } & \multicolumn{2}{|c|}{ Sum of Squares } & \multirow{2}{*}{$\begin{array}{c}\text { Mean Square } \\
57.283\end{array}$} & \multirow{2}{*}{$\mathrm{F}$} & \multirow{2}{*}{ Sig. } \\
\hline & Regression & 286.417 & & & \\
\hline & Residual & 1309.204 & 14.710 & 3.894 & 0.000 \\
\hline & Toplam & 1595.621 & & & \\
\hline
\end{tabular}

Enter yöntemiyle gerçekleştirilen çoklu regresyon analizinin sonuçları Tablo 12'de ifade edilmiştir.

Tablo 12: Içsel Motivasyon \& Cam Tavan Algısı- Model

\begin{tabular}{c|lccccc}
\hline \multirow{2}{*}{ Cam Tavan Algısı } & $\beta$ & $\mathrm{t}$ & Sig. & $\mathrm{R}^{2}$ & $\begin{array}{c}\text { Adjusted } \\
\mathrm{R}^{2}\end{array}$ \\
\cline { 2 - 7 } İçsel & Constant & 9.817 & 2.855 & 0.005 & & \\
Motivasyon & Oadınlara Yönelik Olumsuz & 0.070 & 0.604 & 0.547 & & \\
& Önyargılar & 0.219 & 1.784 & 0.078 & & \\
Aile Hayatı & 0.081 & 0.340 & 0.735 & 0.180 & 0.133 \\
& Cinsiyet Ayrımcılığı & 0.341 & 2.939 & 0.004 & & \\
& Örgüt Kültürü ve Politikalar & & & & \\
Kadınların Kariyer & -0.392 & -2.417 & 0.018 & & \\
Basamaklarında & & & & & \\
Yükselmelerindeki Etkenler & & & & & \\
\hline
\end{tabular}

Bu tablo incelendiğinde; içsel motivasyondaki değişimin \%13,3'ünü cam tavan algısının iki boyutundaki değişimin açıkladığı saptanmıştır. Bu sonuçlara göre içsel motivasyonun alabileceği değer aşağıdaki şekilde formüle edilmiştir;

"İçsel Motivasyon $=9.817+(0.341$ x Örgüt Kültürü ve Politikalar $)-(0.392$ x Kadınların Kariyer Basamaklarında Yükselmelerindeki Etkenler)" 
Lojistik Sektöründe Çalışan Kadınların Motivasyonlarının Cam Tavan Algıları Açısından Değerlendirilmesi

Regresyon analizi sonucunda elde edilen bu formüle göre; cam tavan algısının örgüt kültürü ve politikalar boyutundaki 1 birimlik artışın içsel motivasyon üzerinde 0.341 birimlik bir artışa, kadınların kariyer basamaklarında yükselmelerindeki etkenler boyutundaki 1 birimlik artışın ise içsel motivasyon üzerinde 0.392 birimlik bir azalışa neden olduğu belirlenmiştir. Aile hayat1, kadınlara yönelik olumsuz önyargılar ve cinsiyet ayrımcılı̆̆ boyutlarının ise diğer cam tavan algısı boyutlarıyla birlikte değerlendirildiğinde içsel motivasyon üzerinde anlamlı bir etkisinin olmadığ 1 saptanmıştır.

Tablo 13'te motivasyonun dişsal boyutu ile cam tavan algısının alt boyutlarına yönelik çoklu regresyon analizinin ANOVA sonuçları görülmektedir. Gerçekleştirilen regresyon analizi sonucunda; oluşturulan modelin anlamlılık değerinin 0.05 'ten küçük olması nedeniyle modelin istatistiksel olarak anlamlılık ifade ettiği belirlenmiştir.

Tablo 13: Dışsal Motivasyon \& Cam Tavan Algisl - ANOVA

\begin{tabular}{|c|c|c|c|c|c|}
\hline \multirow{4}{*}{ Dişsal Motivasyon } & \multicolumn{2}{|c|}{ Sum of Squares } & Mean Square & $\mathrm{F}$ & Sig. \\
\hline & Regression & 1773.063 & 354.613 & & \\
\hline & Residual & 6402.621 & 71.940 & 4.929 & 0.000 \\
\hline & Toplam & 8175.684 & & & \\
\hline
\end{tabular}

Enter yöntemiyle gerçekleştirilen çoklu regresyon analizinin sonuçları Tablo 14'te ifade edilmiştir.

Tablo 14: Dışsal Motivasyon \& Cam Tavan Algısı - Model

\begin{tabular}{c|lccccc}
\hline \multirow{2}{*}{$\begin{array}{c}\text { Dişsal } \\
\text { Motivasyon }\end{array}$} & $\beta$ & $\mathrm{t}$ & $\mathrm{Sig}$. & $\mathrm{R}^{2}$ & $\begin{array}{c}\text { Adjusted } \\
\mathrm{R}^{2}\end{array}$ \\
\cline { 2 - 7 } & Constant & 23.088 & 3.036 & 0.003 & & \\
Kadınlara Yönelik Olumsuz & -0.314 & -1.227 & 0.223 & & \\
Önyargılar & & & & & \\
& Aile Hayatı & 0.702 & 2.584 & 0.011 & & \\
& Cinsiyet Ayrımcılığı & -0.252 & -.477 & 0.635 & 0.217 & 0.173 \\
& Örgüt Kültürü ve Politikalar & 0.918 & 3.582 & 0.001 & & \\
Kadınların Kariyer & & & & & \\
Basamaklarında & -0.570 & -1.588 & 0.116 & & \\
Yükselmelerindeki Etkenler & & & & & \\
\hline
\end{tabular}

Bu tablo incelendiğinde; dışsal motivasyondaki değişimin \%17,3'ünü cam tavan algısının iki boyutundaki değişimin açıkladığı saptanmıştır. Bu sonuçlara göre dışsal motivasyonun alabileceği değer aşağıdaki şekilde formüle edilmiştir;

"Dışsal Motivasyon $=23.088+(0.702 \times$ Aile Hayatı $)+(0.918 \times$ Örgüt Kültürü ve Politikalar)"

Regresyon analizi sonucunda elde edilen bu formüle göre; cam tavan algısının aile hayatı boyutundaki 1 birimlik artışın dışsal motivasyon üzerinde 0.702 birimlik bir artışa, örgüt kültürü ve politikalar boyutundaki 1 birimlik artışın ise dışsal motivasyon üzerinde 0.918 birimlik bir artışa neden olduğu 
saptanmıştır. Kadınlara yönelik olumsuz önyargılar, cinsiyet ayrımcılığı ve kadınların kariyer basamaklarında yükselmelerindeki etkenler boyutlarının ise diğer cam tavan algısı boyutlarıyla birlikte değerlendirildiğinde dışsal motivasyon üzerinde anlamlı bir etkisinin olmadığı saptanmıştır.

\section{Sonuç ve Tartıșma}

Lojistik sektörü kadınlar için dezavantajlı bir sektör olmasına rağmen kadınların eğitim seviyesinin her geçen gün biraz daha yükselmesi ve iş dünyasında yaşanan insan haklarına yönelik gelişmeler kadınlar için dezavantajlı olan bu sektörde daha fazla kadın çalışanın istihdam edilmesine yol açmıştır. Başka bir deyişle bu gelişmeler bu sektörü kadınlar için daha cazip bir hale getirmiştir. Kadın çalışanların bu sektörde daha fazla istihdam edilmesi ve eğitim seviyelerinin her geçen gün biraz daha artması üst yönetim pozisyonunda bulunan kadın yönetici sayısında da aynı oranda bir artışa yol açmıştır. Ancak bütün bu olumlu gelişmelere rağmen bu sektörde çalı̧̧an üst düzey kadın yönetici sayısı halen istenilen düzeye ulaşamamıştır. Bu nedenledir ki bu çalışmada kadınların yükselmelerinin önündeki engellerden biri olduğunu düşündüğümüz cam tavan algısı incelenmiştir. Bu çalışmada cam tavana nelerin sebep olduğu ve cam tavanın çalışan motivasyonu üzerindeki olumsuz etkisi ortaya konulmaya çalışılmıştır. Ayrıca bu çalışmada karar alıcılara cam tavanı ortadan kaldırabilecek uygulamaların neler olabileceği konusunda önerilerde bulunulmuştur.

Araştırma sonucunda cam tavan algisı ile motivasyon arasında negatif yönde ve düşük düzeyde anlamlı bir ilişki olduğu saptanmıştır. Ayrıca motivasyonun dışsal alt boyutu ile cam tavan algısı arasında negatif yönde ve düşük düzeyde anlamlı ilişki olduğu saptanırken, motivasyonun diğer alt boyutu olan içsel motivasyon ile cam tavan algısı arasında ise istatistiksel olarak herhangi bir ilişkiye rastlanamamıştır. Ortaya çıkan bu sonuç çalışanların motivasyonuna cam tavan algısından daha çok dişsal motivasyon kaynaklarının (ücret, iş-aile dengesi, arkadaşlık ortamı, yan ödemeler, iş güvencesi vs.) etki ettiğini göstermektedir. Başka bir deyişle bu sonuç kadın çalışanları motive eden faktörlerin dışsal faktörler olduğunu göstermektedir. Ayrıca bu sonuç birçok kadın çalışanın kariyer ilerlemelerinde hiçbir endişe taşımadıklarını ya da kariyer ilerlemesini kendilerine sorun etmediklerini dolayısıyla da bu durumun içsel motivasyonlarını etkilemediklerini göstermektedir.

Cam tavan algısının alt boyutları ile motivasyon arasındaki ilişkinin incelenmesi sonucunda ise cam tavan algısının; cinsiyet ayrımcılığı, aile hayatı, örgüt kültürü ve politikaları alt boyutlarının motivasyonla negatif yönde ve düşük düzeyde anlamlı bir ilişki içerisinde olduğu görülmektedir. Elde edilen bu sonuçlar kadın çalışanların motivasyonunun düşük çıkmasında; bir kadın çalışanın işyerinde cinsiyet ayrımcılığına uğramasının ya da bu durumu hissetmesinin, iş ile aile hayatı arasında bir denge kuramamasının, örgüt 
kültürünün ve uygulanan politikaların cinsiyet ayrımcıllğııı destekler nitelikte olmasının etkili olduğunu göstermektedir.

Cam tavan algısının alt boyutlarının motivasyonun içsel alt boyutuyla olan ilişkisinin incelenmesi sonucunda ise; cam tavan algısının alt boyutları olan; örgüt kültürü ve politikalar boyutu ile içsel motivasyon boyutu arasında pozitif yönde ve düşük düzeyde, kadınların kariyer basamaklarında yükselmelerindeki etkenler boyutu ile içsel motivasyon boyutu arasında ise negatif yönde ve düşük düzeyde anlamlı bir ilişki olduğu tespit edilmiştir. Elde edilen bu bulgular bir örgütün kültürünün ve uyguladığı politikaların kadın çalıșanların üst düzey yöneticiliğe yükselmelerini destekler nitelikte olduğunda kadın çalışanların içsel motivasyon düzeyinin artacağını, tersi durumunda ise azalacağını göstermektedir. Yani kadın çalışanların desteklendiği bir kültüre ve politikalara sahip bir kurumda kadın çalışanlar örgüt içerisinde kişisel yetenek ve becerilerini kullanma firsatı bulabilecek dolayısıyla işlerinden duydukları tatmin düzeyi artacaktır. Kadın çalışanların erkeklere göre daha fazla, yeteneklerine göre ise daha düşük konumlarda çalıştırılmasının ve kariyer gelişimlerinin üstleri tarafından engellenmesinin kadın çalışanların içsel motivasyon düzeylerini azaltacağı görülmektedir.

Cam tavan algısının; aile hayatı, örgüt kültürü ve politikalar, cinsiyet ayrımcılığı alt boyutları ile dışsal motivasyon arasındaki ilişki incelendiğinde ise dışsal motivasyon ile cam tavan algısının aile hayatı, örgüt kültürü ve politikalar alt boyutları arasında pozitif yönde ve düşük düzeyde, cinsiyet ayrımcılığı alt boyutu ile de negatif yönde ve düşük düzeyde anlamlı bir ilişki olduğu saptanmıştır. Kadınların çok fazla ailevi sorumluluk üstlenmeleri, iş ve aile yaşantısı arasında denge kurmakta zorlanmaları, ailesine yeteri kadar zaman ayıramamaları, kariyer gelişimi için aile hayatından fedakârlık yapmaları gibi olumsuz durumların onların dışsal motivasyon düzeylerini azaltacağı, buna karşın kadınların birtakım takviyelerle ailevi sorumluluklarını azalttıkları, iş ve aile yaşamı arasında denge kurdukları ve zaman yönetimini iyi yaptıkları taktirde ise dışsal motivasyon düzeylerini artırabilecekleri tespit edilmiştir. Şirketlerin üst düzey yöneticiliklerde erkekleri tercih etmeleri, kadınlara iş eğitimi konusunda yeterli fırsat vermemeleri, kriz dönemlerinde ilk olarak kadınları işten çıkarmaları, kadınları maaş, prim, statü gibi konularda ayrımcılığa maruz bırakmaları ve iş yaşamını erkeklerin kuralına göre yönetmeleri gibi işletme politikalarının ise kadın çalışanların dışsal motivasyon düzeyini azaltacağ saptanmıştır. Şirketlerde kadın lehine uygulanacak pozitif ayrımcılığa yönelik olumlu politikaların ise kadın çalışanların dışsal motivasyon düzeylerini artıracağı tespit edilmiş̧tir. Erkeklere terfi konusunda daha fazla imkân verilmesinin, kadınların astları ve üstleri tarafından dikkate alınmamasının, kadınların kendilerine yönelik kariyer engelleri olduğunu düşünmesinin, cinsiyetin üst düzey yöneticilikte gereken ve etkileyici vasıflardan biri olduğunu kabullenmesinin ise kadın çalışanların dışsal motivasyon düzeylerini azaltacağı görülmektedir. $\mathrm{Bu}$ sonuçlar cinsiyet ayrımcıllğında görülen artışın kadın 
çalışanların dışsal motivasyon düzeylerinde bir azalışa neden olduğunu göstermektedir.

Araştırmadan elde edilen bu bulgular daha önce bu konuda yapılmış çalışmaların sonuçlarıyla karşılaştırıldığında sonuçlarda benzerliklerin ve farklılıkların olduğu ve bu farklılıkların da çalışılan sektörün ve katılımcıların özelliklerinden kaynaklandığı görülmektedir. Çakar Özenç ve Salepçioğlu (2019) "pilot" ile "polis" mesleğinde çalışan kadınların kariyer engellerinin ve cam tavan algılarının iş motivasyonları ile ilişkisini belirlemek üzere yaptıkları bir çalışmada, kadınların cam tavan algıları ile genel ve içsel motivasyonları arasında istatistiksel açıdan pozitif yönde ve yüksek düzeyde anlamlı bir ilişki olduğunu, cam tavan algıları ile dışsal motivasyonları arasında ise istatistiksel açıdan olumsuz ve orta düzeyde bir ilişki olduğunu saptamışlardır. Bu bulgular kadınlara yönelik mesleki ayrımcılı̆̆ın kadınların genel ve içsel motivasyonunu arttırdığını, dışsal motivasyonlarını ise azalttığını göstermektedir. Oysaki cam tavan algısının kadın çalışanların motivasyonunu düşürmesi beklenirken artırıyor olması bu sektördeki kadın çalışanların kendilerine zor hedefler koyduğunu ve bu hedefler doğrultusunda motive olduklarını göstermektedir (Çakar Özenç ve Salepçioğlu, 2019: 329). İmadoğlu vd., (2020) ise özel sektörde çalışan 33 kadın üzerine yaptıkları bir çalışmada; cinsiyet ayrımcılığının olmamasının, kadın çalışanların başarılarının değerlendirilmesinin, üst yönetimin desteğinin sağlanmasının, personeller arasında eşit uygulamaların ve özgür çalışma ortamının varlı̆̆ının, kadın çalışanlara mentorluk yapılmasının ve psikolojik destek sağlanmasının, diğer kurumlara olumlu yönde örnek olunmasının, kadınların gelişimi için eğitime önem verilmesinin, iş-aile dengesinin kurulmasının, sıcak bir iş çevresi için iş dışında sosyal aktiviteler yapılmasının, daha huzurlu bir iş ortamı yaratılmasının, yönetici ile personel arasındaki ilişkiyi güçlendirmenin, eşit ücret dağılımının ve promosyonların, güven inşa etmenin kadın çalışanların motivasyonunu artıracağını ileri sürmüşlerdir. $\mathrm{Bu}$ çalışmadan elde edilen bulgular kadına yönelik olumlu politikaların kadın çalışanların motivasyonunu artıracağını göstermektedir. İmadoğlu vd., (2020)'nin bu bulguları çalışmamızdan elde edilen bulgularla tutarlılık göstermektedir (İmadoğlu vd., 2020: 98). Imam vd., (2013) ise Pakistan'da bulunan farklı bankalarda çalışan kişiler üzerine yaptıkları bir çalışmada, cam tavan algısının çalışanların iş motivasyonunda bir düşüşe neden olduğunu tespit etmişlerdir. Imam vd., (2013) 'nin çalışmasından elde edilen bulgular çalışmamızdan elde edilen bulguları destekler niteliktedir (İmam, 2013: 264).

Yapılan analizler sonucu elde edilen bulgulardan cam tavan algisının kadın çalışanların motivasyonunu olumsuz yönde etkilediği anlaşılmaktadır. Cam tavanın bu olumsuz etkilerini ortadan kaldırmak için karar alıcılar birtakım önlemler almak zorundadırlar. Bu önlemler kapsamında karar alıcılar; kadın çalı̧̧anlarının kişisel gelişimlerini sağlayacak şekilde mesleki ve lisansüstü eğitimlere çalışanlarını yönlendirmeli, kadın çalışanlara rol model olabilecek başarılı kadın yöneticilerin diğer kadın çalışanlara mentorluk etmesini 
Lojistik Sektöründe Çalışan Kadınların Motivasyonlarının Cam Tavan Algıları Açısından Değerlendirilmesi

sağlamalıdırlar. Yine bu süreçte karar alıcılar erkek egemen iletişim ağlarını sonlandırmalı ve kadın çalışanlara en azından bazı konularda pozitif ayrımcılık yapmalıdırlar. Ayrıca çocuklu kadın çalışanların iş kalitelerini artıracak kreş gibi destek faaliyetlerini de hayata geçirmelidirler.

Gelecekte cam tavan algısı üzerine çalışma yapacak olan araştırmacılara cam tavan algısı ile ilişki içerisinde olduğu düşünülen daha önce çalışılmamış özellikle de yönetim literatürüne yeni girmiş bazı kavramlarla cam tavan algısının bağlantısının incelenmesi önerilmektedir. Ayrıca cam tavan algısının yarattığı olumsuz sonuçların düzeyi her sektörün dinamiği açısından farklı olacağından cam tavan algısının her sektör bazında ölçülmesi gelecekte bu konu üzerinde çalışma yapacak olan araştırmacılara farklı ve ilginç sonuçlara ulaşabilecekleri düşüncesiyle tavsiye edilmektedir. Bu çalışmada incelenen konunun cam tavan algısı olması ve cam tavan algısının kendine has özelliğinden dolayı çalışmanın örnekleminin sadece kadın çalışanlardan oluşması araştırmanın sınırlandırmasını, zaman ve maliyet kısıtı nedeniyle araştırmanın sadece Mersin ilinde yapılıyor olması ise araştırmanın sınırlılığını oluşturmaktadır.

\section{Kaynaklar}

Akdemir, B. ve Çalış Duman, M. (2017). Kadın Çalışanların Performansında Cam Tavan Sendromu Engeli!. International Journal of Academic Value Studies, 3(15), 517-526.

Alhassan, N. ve Greene, E. (2020), Individual Approach to Employee Motivation: Is It Worthwhile in The 21st Century?. International Journal of Global Business, 13(1), 16-24.

Al-Zawahreh, A. ve Al-Madi, F. (2012). The Utility of Equity Theory in Enhancing Organizational Effectiveness. European Journal of Economics, Finance and Administrative Sciences, 46, 158-170.

Arnania-Kepuladze, T. (2010). Gender Stereotypes and Gender Feature of Job Motivation: Differences or Similarity? Problems and Perspectives in Management, 8(2), 84-93.

Can, E., Kaptanoğlu, S. ve Halo, L. M. (2018). Akademisyenlerde Cam Tavan Sendromunun Güç Mesafesi İle İlişkisi. Marmara Üniversitesi Öneri Dergisi, 13(50), 52-64.

Cummins, H. A. (2012). Queen Bees and Mommy Tracking: How's an Academic Woman Supposed to Get Ahead?. Advancing Women in Leadership Journal, 32, 79-91.

Çakar Özenç, M. ve Salepçioğlu, M. A. (2019). Erkek Egemen İşlerde Çalışan Kadınlarda Cam Tavan Sendromu ve İş Motivasyonu. Anadolu Bil Meslek Yüksekokulu Dergisi, 56, 313-333.

Daud, I. (2020). The Influence of Organizational Culture and Compensation on Employee Performance with Work Motivation as a Mediating Variable. Journal of Management and Marketing Review, 5(2), 122-128. 
Eliyahu, A. S., Bibu, N. ve Danaiata, D. (2020). Organizational Politics and Its Influence on Employees' and Volunteers' Motivation in Emergency Organizations in Israel. Review of International Comparative Management, 21(2), 251-264.

Ertan, H. ve Ağca, V. (2008). Örgütsel Bağlllık, İş Motivasyonu ve $\dot{I}_{S ̧}$ Performansı Arasındaki IIlişki: Antalya'da Beş Yıldızlı Otel İşletmelerinde Bir Inceleme, Afyonkarahisar Kocatepe Üniversitesi Sosyal Bilimler Enstitüsü, Doktora Tezi.

George, D. ve Mallery, P. (2003). SPSS for Windows Step by Step: A Simple Guide and Reference, Boston, MA: Allyn \& Bacon.

Hassoo, A. K. ve Akbay, C. (2020). Factors Affecting Motivation of Employees in Public Sector: Case Study in Erbil, Iraq. Review of International Comparative Management, 21(3), 412-422.

Herzberg, F. (1959). The Motivation to Work, New York: Wiley.

Hymowitz, C. ve Schellhardt, T. D. (1986). The Glass-Ceiling: Why Women Can't Seem to Break The Invisible Barrier That Blocks Them from Top Jobs. The Wall Street Journal, 57, D1, D4-D5.

Irmak, R. ve Budak, G. (2010). Cam Tavan Sendromu-Bir Hastane Uygulamasl, Dokuz Eylül Üniversitesi Sosyal Bilimler Enstitüsü, Yüksek Lisans Tezi.

İmadoğlu, T., Kurşuncu, R. S. ve Çavuş, M. F. (2020). The Effect of Glass Ceiling Syndrome on Women's Career Barriers in Management and Job Motivation. Holistica, 11(2), 85-99.

İmam, A., Shah, F. T. ve Raza, A. (2013). Mediating Role of Job Stress between Workplace Discrimination Gender Discrimination-Glass Ceiling and Employee Attitudinal Outcomes Job Satisfaction and Motivation in Banking Sector of Pakistan. Middle-East Journal of Scientific Research, 18(2), 264-274.

Kurt, S. ve Akgün Kostak, M. (2019). Sağlık Bilimleri Fakültesi Öğrencilerinin Cam Tavan Sendromu Hakkındaki Görüşleri. Uluslararası Sosyal Araştırmalar Dergisi, 12(65), 859-866.

MIP, (2018). Mersin International Port Panorama, 16 Haziran 2020 tarihinde Mersin Uluslararas1 Liman1: https://www.mersinport.com.tr/images/pdf/ MIP_Panorama_2018_4Q.pdf adresinden alınd1.

Mottaz, C. J. (1985). The Relative Importance of Intrinsic and Extrinsic Rewards as Determinants of Work Satisfaction. Sociological Quarterly, 26(3), 365385.

Mulyani, S. R., Sari, V. N. ve Sari, M. W. (2019). The Model of Employee Motivation and Cooperative Employee Performance. Polish Journal of Management Studies, 20(2), 379-390.

Okoth, V. A. ve Florah, O. M. (2019). Motivation and Employee Performance at Avenue Hospital Kisumu County- Kenya. Business Management Dynamics, 9(05), 20-36. 
Lojistik Sektöründe Çalışan Kadınların Motivasyonlarının Cam Tavan Algıları Açısından

Değerlendirilmesi

Panait, C. A. (2020). Study of Employee Motivation in Organizations. Global Economic Observer, 8(1), 114-119.

Sahoo, D. K. ve Lenka, U. (2016). Breaking The Glass Ceiling: Opportunity for The Organization. Industrial and Commercial Training, 48(6), 311-319.

Schermelleh-Engel, K., Moosbrugger, H. ve Müller, H. (2003). Evaluating The Fit of Structural Equation Models: Tests of Significance and Descriptive Goodness-of-Fit Measures. Methods of Psychological Research Online, $8(2), 23-74$.

Thomas, K. W. (2009). Intrinsic Motivation at Work: What Really Drives Employee Engagement. San Francisco: Berrett-Koehler Publishers.

Yörük Karakılliç, N. (2019). Evaluation of Glass Ceiling Syndrome in Terms of Gender Discrimination Perception. Yönetim ve Ekonomi Araştırmaları Dergisi, 17(2), 214-233.

Yusoff, W. F. W., Kian, T. S. ve Idris, M. T. M. (2013). Herzberg's Two Factors Theory on Work Motivation: Does Its Work for Todays Environment? Global Journal of Commerce \& Management Perspective, 2(5), 18-22. 